\title{
DYNAMIC INFORMATION SYSTEMS TO MANAGE DATA SCHOOLS
}

\section{Jan LAVRINČÍK}

\begin{abstract}
The article deals with the significance dynamic systems for data management of school with alignment university school for foreign visit. It explains which parts consist of database software; the selection of programming language from the point of view compatibility, development, and future extended are emphasized. The paper describes development, control, possibilities improve, and practical application program: System of records foreign visit. It information with hierarchy structure authorized process. The article is supplement about flow diagram.
\end{abstract}

Key words: Erasmus, Free mover, information system, Mobility, foreign visit, school information system.

\section{DYNAMICKÉ INFORMAČNÍ SYSTÉMY PRO SPRÁVU DAT ŠKOLY}

Resumé: Článek popisuje a klasifikuje dynamické systémy pro správu školy, se zaměrením na vysokoškolské systémy pro evidenci zahraničních mobilit. Vysvětluje z jakých částí se databázový program skládá, zdůrazňuje výběr programovacího jazyka zhlediska kompatibility, vývoje a budoucího rozšiření. V nosné části se zaměřuje na vývoj, ovládání, možnosti vylepšení a praktické využití aplikace Systém evidence zahraničnich pobytů. Seznamuje čtenáre s hierarchickou strukturou schvalovacích procesů. Přispěvek je doplněn o vývojové diagramy.

Klíčová slova: Erasmus, Free mover, informační systémy, Mobility, školní informační systémy, zahranični pobyt.

\section{1 Úvod}

Informační systémy pro správu dat školy si velmi rychle našli své autonomní místo na českých školách a přinášejí celou řadu výhod a usnadnění práce pro učitele, žáka a rodiče. Systémy vycházejí $z$ ověřených poznatků o databázích a jejich chování v podnikové sféře a managementu, kde se díky požadavkům na racionalizaci a ekonomizaci informačních toků použivají o několik let déle. V edukačním prostředí je mezi prvky systému realizovaná výměna informací v návaznosti na složkách informační a edukační. U systémů jsou charakteristické funkce modelování ekonomických procesů, přihlašovací a evidenční systémy, podpora výuky žáka, testování apod.

V současné době se stávají moderním a důležitým prvkem výuky výměnné studijní pobyty nebo několikadenní studijní stáže na různých typech škol, počínaje primárním až k terciálnímu vzdělávání. Přinášejí nejen možnost zdokonalovat se $\mathrm{v}$ integračním jazyce EU nebo jiném světovém jazyce, ale i porovnávat studijní a vědecké poznatky s kolegy $\mathrm{z}$ jiných států po celém světě.

Příspěvek se snaží definovat dynamické systémy pro správu dat školy, navrhnou jejich klasifikaci $\mathrm{s}$ přihlédnutím $\mathrm{k}$ potřebám databázových aplikacím pro výběr studentů pro zahraniční pobyty. Jako funkční model je nastíněno fungování aplikace SEZP, používané od akademického roku 2008/2009 pro výběr zahraničních pobytů.

\section{Dynamické systémy pro správu dat školy}

Definováním školních informačních systémů se již zabývaly studie (1), (2), (3) a definovaly je jako soubor lidí, metod a technických prostředků, zajišt’ujících sběr, uchování, analýzu a prezentaci dat určených pro poskytování informací z oblasti vzdělávání. Do pojetí definice můžeme zahrnout software určený $\mathrm{k}$ výuce, ekonomice, řízení i obecné programy. Z pohledu dynamických databázových systémů pro mobility žáků/studentů nejsou definována žádna kritéria pro jejich provoz. V následujícím dělení se pokusíme naznačit důležité otázky dotýkající se řešené problematiky a mající význam na volbu takto orientovaného software. Pro klasifikaci jsme využili studií (4), (5).

Informační systémy $\mathrm{s}$ akcentem na systémy pro zahraniční pobyty ve vzdělávání můžeme klasifikovat dle:

a) Dle typu vadělávací instituce pro kterou jsou určeny: 
- Základní školy;střední školy, vysoké školy, univerzálni a pro ostatni vzdélávací instituce.

Základní kritérium je zaměření na aplikace dle typu př́ijemce. Každá instituce i ve vzdělávání má individuální nároky na své informační systémy, sleduje jiná kritéria a ukazatele, se kterými dále pracuje a rozvíjí je. Univerzální aplikace nabízejí široké spektrum použití, ale často se vypořádávají s kompromisy a své uživatele odrazují vysokou cenou. Aplikace určené speciálně pouze pro konkrétní vzdělávací stupeň mohou rozpracovávat tematiku do hloubky a nabídnout jednoduchost a snadnou obsluhu.

b) Dle offline $x$ online funkčnosti:

- Off-line, on-line, off-line sonline podporou.

Aplikace můžeme dělit dle rozhraní pro které jsou určené (on-line, off-line). Databázové systémy při použití velkých databázových systémů se prímo řadí do skupiny on-line, protože se jedná většinou o programy využívající externí databázi, se kterou prostřednictvím sítě udržují spojení. Navíc se od systémů s primární funkcí zahraničních pobytů předpokládá i možnost přistoupit z jiného, než domovského počítače.

\section{c) Dle použitého databázového systému:}

- Uživatelské, velké databázové systémy.

Databáze můžeme klasifikovat dle typu a funkce na uživatelské a velké databázové systémy. Velké pozornosti se z uživatelských dostává zejména databázím Microsoft Access, protože jsou součástí kancelářského balíčku a dají se pomocí něj i editovat. Z velkých databázových systémů se nejběžněji díky licenci setkáváme s MySQL. Umožňují bezplatně využívat výhod velkých databázových systémů $\mathrm{v}$ různých prostředích (w32 aplikace, $\mathrm{PHP}$ ).

\section{d) Dle počtu uživatelu:}

- Monouživatelský administrativa),

(̌̌kolská

(učitel, student správce).

Součástí rozhodování jsou i aktérii, kteří se od sebe liší zájmy, hodnotami, postoji a možnostmi ovlivňovat rozhodování. Dle počtu uživatelů dělíme školské informační systémy na monouživatelské a polyuživatelské. Dělení má vliv a vychází zejména $\mathrm{z}$ oprávnění jednotlivých uživatelů. Nejmenší uživatelská práva mají žáci (studenti), kteří mají oprávnění pouze pro čtení svých údajů, učitel může u svých předmětů zadávat údaje (známky, docházka, apod.) a správce systému, který může zadávat a měnit veškteré údaje, vč. správy a záloh systému.

e) Dle zaměření a funkcí informačního systému

$\begin{array}{lr}\text { - } & \begin{array}{l}\text { Sjednostanným } \\ \text { (ASCtimetables, }\end{array} \\ \text { s univerzálním } & \text { zaměřením } \\ \text { (Bakalárí). } & \text { Samířením }\end{array}$

Poslední předkládaná klasifikace člení školní systémy dle zaměření a funkcí informačního systému. $Z$ jednostranně uživatelsky zaměřených informačních systémů můžeme jmenovat ASCtimetables - aplikaci na tvorbu rozvrhů, Smile - aplikace na tvorbu a správu školních vzdělávacích programů. Univerzální programy obsahují spektrum modulů, kterými se snaží pokrýt celou vzdělávací oblast (STAG, Bakaláři).

Pro oblast školství jsou typické změny, které přinášejí nový a zajímavý software, což může vést $\mathrm{k}$ nutnosti změn navrhované klasifikace. Našim záměrem nebylo podat vyčerpávající výčet možností klasifikace, pouze se zaměřit na oblasti, které úzce souvisejí se stěžejní třetí kapitolou s akcentem na edukační proces terciálního vzdělávání.

\section{Systém evidence zahraničních mobilit}

Ve třetí kapitole si ukážeme praktický návrh školního informačního systému určeného primárně pro terciální vzdělávání. U aplikací pro vysoké školy není na trhu taková nabídka a některé systémy nejsou zatím zpracovány od renomovaných společností. V takových př́ípadech se jeví optimální zvolit autorský prŕístup, který vede $\mathrm{k}$ vytvoření jedinečného autonomního systému.

Celá aplikace je rozdělena do tří velkých částí, pro lepší představu uvedených na vývojovém digramu č. 1. Stěžejní a nejvíce používanou částí je část Erasmus určená pro výjezdy studentů bakalářských a magisterských studijních programů PdF UP. Pro pobyty tohoto typu je typické, že mají studenti $\mathrm{k}$ dispozici pouze na výběr ze zahraničních škol dle seznamu. Jednotlivé katedry na základě podepsaných smluv zajistí pomocí koordinátorů místa výjezdu. Nejběžněji se jedná o sousední Slovensko, ale nejsou vyloučeny ani nabídky pobytů do Slovinska, Finska či Anglie.

Č́st pro studenty je typická použitím jednorázového prrístupu pomocí vygenerování jednorázového př́stupu (generovaného kódu a zabezpečeným př́stupem pomocí algoritmu 
RC4+). Student má za povinnost vyplnit několik sad povinných buněk. Sady jsou tematicky členěné, na informace o studentovi, domovské škole, hostitelské škole a studovaných předmětech. Informace o hostitelské škole jsou v malé databázi tvořené $\mathrm{z}$ textového souboru včetně všech údajů (kontakt, adresa, kontaktní osoba apod.). Ze studovaných předmětů má student za povinnost si dovést $\mathrm{z}$ hostitelské školy minimálně 10 kreditů. Student má $\mathrm{k}$ dispozici standardně pouze jeden předmět, který si může rozširrìit až na dvanáct, když přepíše příslušné číslo jedna $\mathrm{v}$ buňce na větší. Numerické buňky jsou chráněné proti přepisu jinou hodnotou než numerickou. Funkčnost kláves schránky $(\mathrm{Ctrl}+\mathrm{c}$, $\mathrm{Ctrl}+\mathrm{v}, \mathrm{Ctrl}+\mathrm{x})$ je zachována i v režimu vzdálené lochy. Algoritmus si zjišt'uje obsah hodnoty ve schránce a podle hodnoty povolí či zakáže její vložení do př́islušné buňky.
Část pro vyučující, koordinátory, proděkanku pro zahraniční styky a děkanku PdF je chráněna uživatelských heslem a jménem. Uživatelů prricházejících do styku se systémem je dohromady více než 70. Každý z uživatelů však v systému plní zcela specifickou funkci, proto jsou rozděleni do sedmi skupin dle prŕstupů (vedoucí kateder, koordinátoři ECTS, koordinátoři Erasmus, proděkanka pro zahraniční styky, děkanka PdF a administrátoři s neomezeným př́stupem). Posloupnost schvalování jednotlivých složek můžeme vidět na vývojovém diagramu č. 2. Diagram je specializovaný pro výjezdy typu Erasmus. Pro části Ostatní mobility a Free Mover se mohou vyskytnout menší odlišnosti, např. absence Erasmus koordinátora apod.

Vývojový diagram 1: Logická stavba programu (6, s. 24), (7, s. 319).

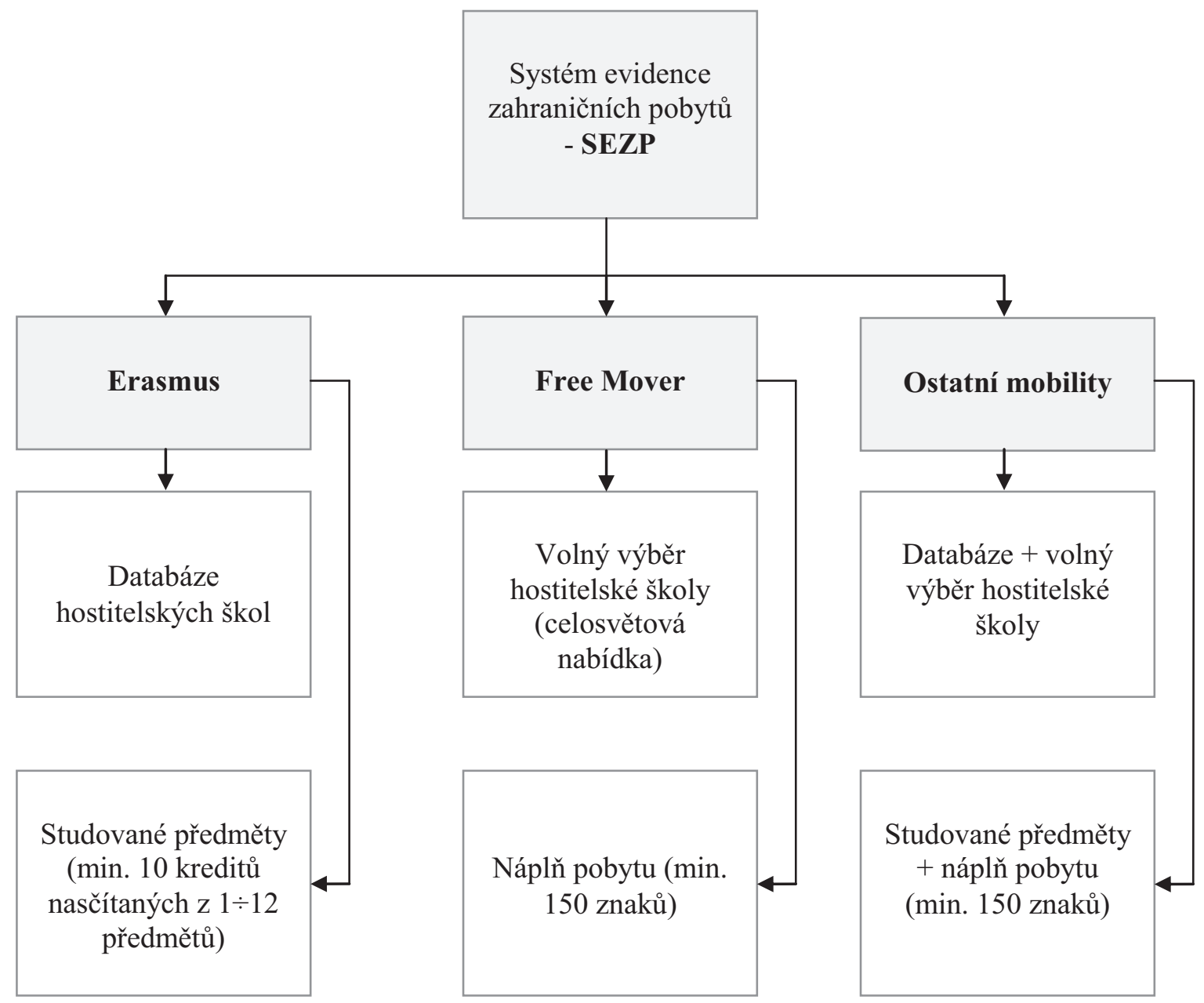


Vývojový diagram 2: Rozhodovací struktura výjezdu Erasmus (aktualizováno dle 7, s. 320).

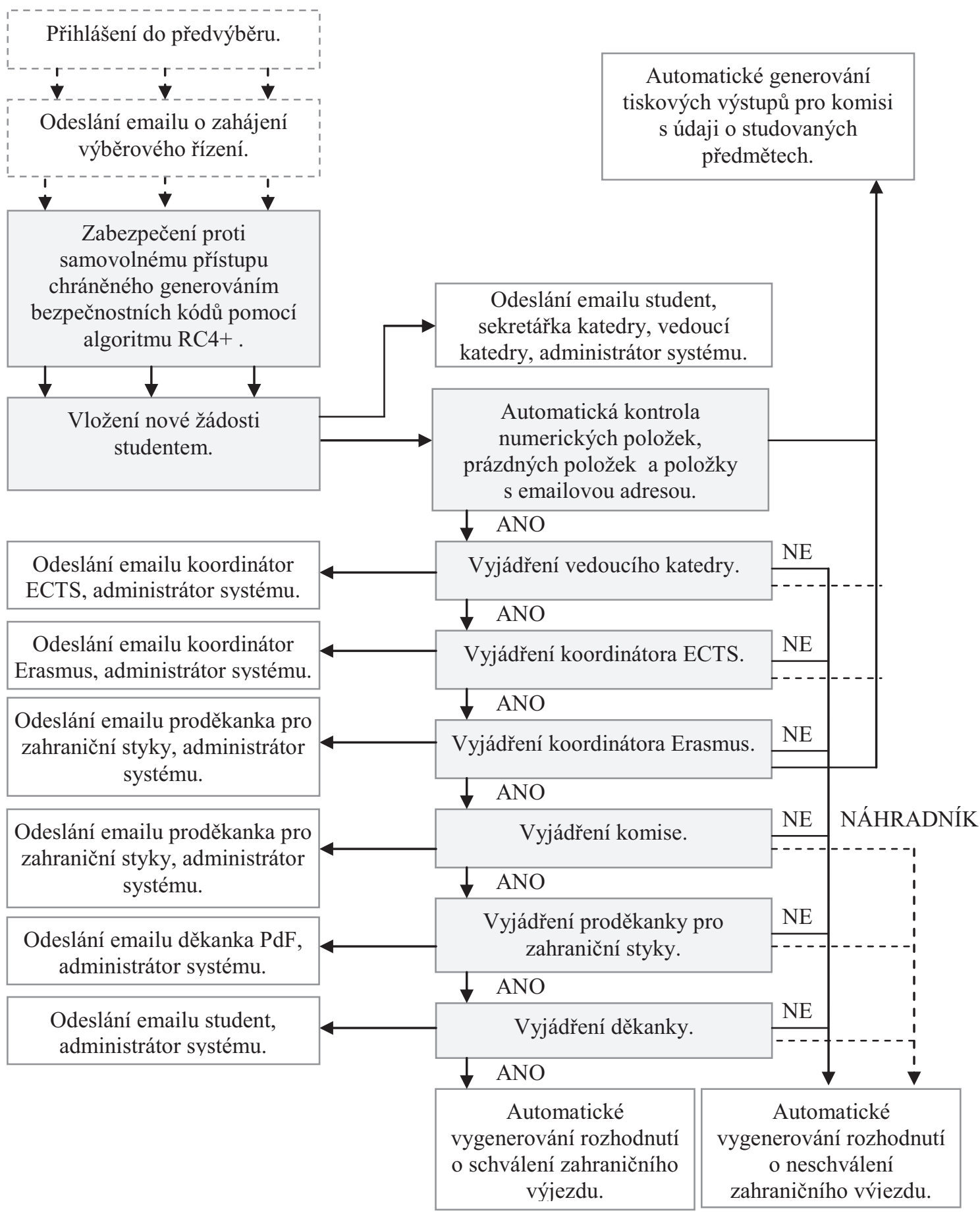

\section{Závěry a doporučení}

Dynamické informační systémy pro správu dat školy jsou užitečným pomocníkem a vybudovali si již své nezastupitelné místo. V některých oblastech, jako např́klad administrativa školy, výukový software je trh přehlcen nabídkou řady výrobců, ale některým složitějším aplikacím se výrobci vyhýbají. Autorský př́stup je jedním z možných efektivních řešení a reakcí na vzniklou situaci. $Z$ vývojových diagramů je patrné, že software přináší zcela nová a originální řešení prrístupů $\mathrm{k}$ informačním systémům pro správu dat školy, ale je patrný i př́nos pro vědu. Jako výhodné by se mohlo jevit i vývoj a nasazení na více školách, což by dopomohlo programu z pohledu vylepšení a sladění software pro různá prostředí. 


\section{Použitá literatura}

[1] DOSTÁL, J. Školní informační systémy. In Infotech 2007 - moderni informačni technologie ve vzdělávání. Olomouc : Votobia, 2007. s. 540 - 546. ISBN 978-807220-308-6. Dostupné na www: $<$ http://infotech.upol.cz $>$.

[2] BASL, J. Informační systémy škol specifická oblast využití managerských informačních systémů. [on-line]. 2006. [cit. 2010-10-03]URL

http://www.ikaros.cz/informacni-systemyskol--specificka-oblast-vyuzitimanazerskych-informacnich-systemu>.

[3] DOSTÁL, J. Školní informační systémy $\mathrm{v}$ praxi. In IKT $v$ technickom vzdelávaní. Banská Bystrica : Univerzita Mateja Bela, 2007. s. 33 - 38. ISBN 978-80-8083-529-3.

[4] DOSTÁL, J. Výukový software a počítačové hry - nástroje moderního vzdělávání. Journal of Technology and Information Education. 2009. Olomouc EU, Univerzita Palackého, Ročník 1, Číslo 1, s. 24 - 28. ISSN 1803-537X.
[5] DOSTÁL, J. Multimédia, hypertextové a hypermediální učební pomůcky - trend soudobého vzdělávání. Journal of Technology and Information Education. 2009. Olomouc - EU, Univerzita Palackého, Ročník 1, Č́́slo 2, s. 18 - 23. ISSN 1803-537X.

[6] KLEMENT, M. Základy programování $v$ jazyce Visual Basic. 1. vyd. Olomouc : VUP, 2002. 336 s. ISBN 80-244-0472-9.

[7] LAVRINČÍK, J., KLEMENT, M. Systém evidence zahraničních pobytů. In Trendy ve vzdélávání 2009. Olomouc: Votobia, 2009, s. 318 - 322. ISBN 978-80-7220-316-1.

\section{Kontaktní adresa:}

Mgr. Jan Lavrinčík, DiS.

Katedra technické a informační výchovy

Pedagogická fakulta UP

Žižkovo nám. č. 5

771 40, Olomouc, ČR

Tel: +420 585635813

E-mail: nobilis.felis@seznam.cz

Www pracoviště: www.kteiv.upol.cz 